\title{
An Efficient Protocol for Isolation of Functional RNA from Peel Tissue of Different Banana (Musa spp.) Cultivars for Gene Expression Studies on Anthracnose Development
}

\author{
U. M. Aruna Kumara and Devika M. De Costa ${ }^{1 *}$ \\ Postgraduate Institute of Agriculture \\ University of Peradeniya \\ Sri Lanka
}

\begin{abstract}
Extraction of good quality RNA in larger quantities is a prerequisite for gene expression studies. Existing protocols for RNA extraction from banana pulp tissues were not successful on peel tissues of banana (Musaspp) as they contain higher concentrations of polyphenols, polysaccharides and latex. This study developed a new protocol by modifying the existing protocols. The modifications included combining of pre-warmed Tris-Borate extraction buffer, incorporation of CTAB in the extraction buffer, incubation in extraction buffer at $65^{\circ} \mathrm{C}$ for one hour, and a three-day long extraction procedure with phenol, phenol:chloroform (1:1) and chloroform:isoamyl alcohol (24:1) together with centrifugation steps at high speeds (i.e. 12,000-14,000 rpm). Spectrophotometric analysis of the extracted $R N A$, denaturing agarose gel electrophoresis, cDNA library construction, sequence information of cDNA inserts and RT-PCR confirmed the quality of RNA extracted by the method developed in the present study for gene expression work. Furthermore, it is shown that the developed method is useful to extract good quality RNA from peel tissues of a range of dessert- and cooking-type banana cultivars.
\end{abstract}

Keywords: cDNA library construction, Colletotricummusae, RNA extraction, RT-PCR

\section{INTRODUCTION}

Banana (Musa spp.) is grown in more than 120 countries worldwide and has been ranked second in world fruit production (Lassoes et al., 2010), and is a vital source of income, employment, and export revenue for many developing countries in Latin America, West Indies, Southeast Asia and Africa. In Sri Lanka, 29 banana cultivars have been reported and among them 22 cultivars are used as dessert banana (et al., 2002). Anthracnose is one of the most economically significant postharvest diseases of dessert banana in Sri Lanka. As reported by Anthony et al. (2004), the postharvest diseases were responsible for $20 \%$ of yield losses in Sri Lanka in 1997. Colletotrichummusae has been reported as the causal organism of anthracnose (Coomaraswamy et al., 2009). Studies based on natural infections and artificial inoculation of $C$. musaehaverevealed that the incidence and severity of anthracnose development at the postharvest stage vary among local banana cultivars (De Costa and

\footnotetext{
1 Department of Agricultural Biology, Faculty of Agriculture, University of Peradeniya, Sri Lanka

*. Corresponding author: devikadecosta@gmail.com
} 
Chandima, 2014). Therefore, studies at gene expression level are essential to elucidate the genetic basis of differential anthracnose development in different banana cultivars.

Isolation of high quality RNA is an important prerequisite for gene expression analyses. However, isolation of high quality RNA from plant tissues rich in polysaccharides and polyphenolic substances is often difficult (Asif et al., 2000). The presence of latex in addition to the above substances affects the quality and the quantity of the RNA extracted. Several methods developed by Doyle and Doyle (1987), Fütterer et al. (1995), Asif et al.(2000) and Liu et al.(1998) have been used to extract total cellular RNA from tissues rich in polysaccharides and polyphenols. Moreover, isolation of RNA for genomic studies has been reported from fruit pulp tissues of banana (Clendennenand May, 1997). However, no method has been reported to isolate RNA for functional studies from banana peel tissues, which are rich in polyphenolic compounds and latex. The amount and specific composition of different polyphenolic compounds in banana peel tissues could vary with the type of banana cultivar (i.e. dessert- or cooking-type) and the maturity stage of the fruit (Iandolino et al., 2004). This further complicates the extraction of total cellular RNA for gene expression studies aimed at determining the genetic basis of differential anthracnose development in different banana cultivars. The major problem in RNA extractions is the co-precipitation of polysaccharides and polyphenols together with RNA (Fütterer et al., 1995; Liu et al., 1998). These compounds bind to RNA and render it unsuitable for gene expression analysis (Vasanthaiah et al., 2008). Therefore, the objective of the present study was to develop an efficient protocol for isolation of high quality functional RNA in higher quantities from banana fruit peel tissues obtained from a range of cultivars for subsequence functional studies, namely construction of a cDNA library, identification of EST sequences towards identification of putative gene responsible for possible resistance to anthracnose development in some banana varieties and also for RT-PCR analyses

\section{METHODOLOGY}

\section{Plant tissues}

Well-grown and fully-maturedi.e.at Maturity index 1according to the standard charts by Kader(2005), banana bunches of cultivarsSeenikesel and Kolikuttu(Musa acuminata)and cultivar Alukesel (M.balbisiana), which were free from external blemishes, were collected randomly from three semi-commercial plantations in Kandy, Sri Lanka. In the field, the banana bunches had been covered with plastic sleeves to avoid natural inoculation ofC.musae.In the case of banana, placing a perforated plastic sleeve around bunches limits the circulation of rainwater and reduces the level of fruit contamination with $C$. musae by more than $82 \%$ (de Lapeyre de Bellaire et al., 2000).

Banana fruits (i.e. fingers) were separated from banana hands and washed with running tap water. Surface sterilization was done by dipping in $10 \%$ commercial bleach solution for 5 min followed by rinsing in sterilized distilled water and subsequent air drying. The surface sterilized fingers were inoculated with an aliquot of $10 \mu \mathrm{l}\left(10^{5}\right.$ spores $\left.\mathrm{ml}^{-1}\right)$ of $C$. musae spore suspension. Two spots per finger were inoculated. Twenty one fruits were inoculated and incubated in incubation chambers at room temperature $\left(28^{\circ} \mathrm{C}\right)$ and $90 \% \mathrm{RH}$. Using three fruits per a given time period, peel tissues were collected from the immediate surroundings of the point of inoculation at one hour before and 1, 24, 48, 96, 144, and 192h after inoculation of $C$. musae to determine the sequence of gene expression along different time intervals, just before and also from the onset of inoculation until symptom development. The 
collected peel tissues were ground separately into a fine powder, with an adequate amount of liquid nitrogen in a $0.1 \%$ Diethylphyrocarbonate (DEPC)-treated motor and pestle and stored at $-80{ }^{\circ} \mathrm{C}$ until further use. The extractedRNA samples were pooled using equal concentrations from each time interval to be used for extraction of mRNA. The extracted RNA was used for a cDNA library construction and subsequent identification of EST sequences that allow identification of putative genes responsible for possible resistance to anthracnose development in some banana cultivars and also for RT-PCR analyses.

\section{Extraction method No. 1}

The RNA extraction method described by Fütterer et al. (1995) was employed as the method No 1 on banana peel tissues of the three cultivars(i.e. Seenikesel, Kolikuttuand Alukesel).An aliquot of $0.5 \mathrm{ml}$ of the extraction buffer [1M TrisHCl (pH 9.0), $50 \mathrm{mM}$ EDTA (pH 8.0), $1 \%$ SDS (w/v)] and $0.5 \mathrm{ml}$ of Phenol:Chloroform:Isoamyl alcohol (24:24:1) was added into the Eppendorf tube containing 500mg of fine powder of banana peel tissues. Content of the tube was shaken well and placed on ice for 1 hour with shaking at every 10 min. Then the samples were centrifuged for $5 \mathrm{~min}$ at $10,000 \mathrm{rpm}(24 \times 3 \mathrm{~g})$ under $4{ }^{\circ} \mathrm{C}$. The aqueous phase was separated and extracted with $0.5 \mathrm{ml}$ of Phenol: Chloroform: Isoamyl alcohol (24:24:1) as described above. Supernatant was collected and re-extracted with $0.5 \mathrm{ml}$ of Chloroform:Isoamyl alcohol (24:1).The supernatant was collected and 1/10 volume of $4 \mathrm{M}$ $\mathrm{LiCl}$ and 2 volumes of $100 \%$ ethanol were added, mixed well and incubated for 30 min at $70{ }^{\circ} \mathrm{C}$. The samples were then centrifuged for $5 \mathrm{~min}$ at $10,000 \mathrm{rpm}$ at $4{ }^{\circ} \mathrm{C}$. Then the pellet that appeared at the bottom of the Eppendorf tube was dissolved in $750 \mu$ l DEPC-treated water, $300 \mu \mathrm{l}$ of $4 \mathrm{M} \mathrm{LiCl}$ was added, mixed well, incubated overnight at $4{ }^{\circ} \mathrm{C}$. Then the samples were centrifuged at $10,000 \mathrm{rpm}$ for $5 \mathrm{~min}$ at $4{ }^{\circ} \mathrm{C}$. Subsequently, the pellet was washed with $100 \%$ ethanol and centrifuged at $10,000 \mathrm{rpm}$ for $5 \mathrm{~min}$ at $4{ }^{\circ} \mathrm{C}$. Finally, the pellet was dried and dissolved in $10 \mu \mathrm{l}$ DEPC water and stored at $-80^{\circ} \mathrm{C}$.

\section{Extraction method No. 2}

The RNA extraction method No. 2 was attempted by combining the methods described by Liu et al. (1998) and Asif et al. (2000). An aliquot of $600 \mu \mathrm{l}$ of extraction buffer [100 mMTrisHCl (pH 7.5), $500 \mathrm{mMNaCl}, 25 \mathrm{mM}$ EDTA (pH 8.0), 1.5\% SDS, $2 \%$ PVP, $0.7 \% \beta-$ mercaptoethanol] was mixed with $500 \mathrm{mg}$ of fine powder of banana peel tissues of cultivarsSeenikesel, KolikuttuandAlukesel.The content was placed on ice with occasional shaking for 1 hour and then centrifuged at $10,000 \mathrm{rpm}(24 \times 3 \mathrm{~g})$ for $15 \mathrm{~min}$ at $4^{\circ} \mathrm{C}$. The supernatant was retained, 1/3 volume of $3 \mathrm{M} \mathrm{NaAc}$ ( $\mathrm{pH}$ 5.2) was added, mixed well and kept on ice for $30 \mathrm{~min}$ followed by centrifugation at $10,000 \mathrm{rpm}$ for $15 \mathrm{~min}$ at $4^{\circ} \mathrm{C}$. The supernatant was transferred to a new tube extract with an equal volume of phenol:chloroform:isoamyl alcohol (24:24:1) and mixed by vigorous vortexing. Afterwards, the phenol and aqueous phase was separated by centrifugation at $10,000 \mathrm{rpm}$ for $10 \mathrm{~min}$. at $4^{\circ} \mathrm{C}$. The aqueous phase extracted was mixed with an equal volume of chloroform:isoamyl alcohol $(24: 1)$ and centrifuged at $10,000 \mathrm{rpm}$ for $10 \mathrm{~min}$ at $4{ }^{\circ} \mathrm{C}$. The aqueous supernatant (upper) phase was transferred to a new tube, 2-3 volumes of absolute ethanol were added and stored for $30 \mathrm{~min}$ at $-80{ }^{\circ} \mathrm{C}$ to precipitate RNA. The RNA was pelleted by centrifuging at $10,000 \mathrm{rpm}$ for $15 \mathrm{~min}$ at $4{ }^{\circ} \mathrm{C}$ and the pellet dissolved inDEPC-treated water was reextracted with phenol:chloroform:isoamyl alcohol (24:24:1) and chloroform:isoamyl alcohol (24:1) and precipitated with absolute ethanol as given in Method No. 1. Inclusion of additional re-extraction steps with phenol and chloroform helped removing contaminants and recoveringa higher quantity of RNA. Inefficient removal of polysaccharides and polyphenolic compounds results in co-precipitation with RNA, which affects its yield and 
quality (Logemann et al., 1987). Thereafter, the RNA was pelleted, the pellet was washed twice with $70 \%$ ethanol and air dried. Then the pellet was dissolved in $10 \mu \mathrm{IDEPC}$ treated water and stored at $-80^{\circ} \mathrm{C}$.

Extraction method No. 3

This extraction method No 3 attempted to extract functional RNA from peel tissues of different banana cultivars of dessert-(i.e. Seenikesel and Kolikuttu) and cooking- (Alukesel) types.In this method, $0.1 \% \quad \beta$ Mercaptoethanol was added to the extraction buffer [100mMTris-Borate (pH 8.2), 1.4 M NaCl, $20 \mathrm{mM}$ EDTA (pH 8), 2\% (w/v) CTAB] prior to pre-warming of the extraction buffer at $65^{\circ} \mathrm{C}$ for $30 \mathrm{~min}$. An aliquot of $1 \mathrm{ml}$ of pre-warmed extraction buffer was added to 500mg of powdered banana peel tissues, mixed thoroughly by vortexing and incubated at $65^{\circ} \mathrm{C}$ for one hour. Samples were cooled to room temperature and centrifuged at $12,000 \mathrm{rpm}(24 \mathrm{x} 3 \mathrm{~g})$ for $15 \mathrm{~min}$ at room temperature. The supernatant was collected into new Eppendorfs and extracted twice with chloroform:isoamyl alcohol (24:1). After centrifuging at $12.000 \mathrm{rpm}$ for $15 \mathrm{~min}$ at room temperature, the supernatant was separated in to new Eppendorfs and mixed with $10 \mathrm{M} \mathrm{LiCl}$ to a final concentration of $3 \mathrm{M}$. Contents were incubated overnight at $4^{\circ} \mathrm{Cand}$ RNA was recovered by centrifuging at 14,000 rpm for $20 \mathrm{~min}$ at $4^{\circ} \mathrm{C}$. The supernatant was decanted carefully and the pellet was dissolved in 500 $\mu \mathrm{l}$ ofDEPC-treated water and extracted thrice with phenol, phenol:chloroform (1:1) and chloroform:isoamyl alcohol (24:1), respectively. The supernatant was mixed with $1 / 30$ volume of $3 \mathrm{M} \mathrm{NaAc}(\mathrm{pH} 5.2)$ and 0.1 volume of absolute alcohol. The mixture was kept on ice for $30 \mathrm{~min}$ and centrifuged at $14,000 \mathrm{rpm}$ for $25 \mathrm{~min}$ at $4^{\circ} \mathrm{C}$. The supernatant was collected carefully without disturbing the white jelly like precipitate and mixed with $3 \mathrm{M}$ $\mathrm{NaAc}(\mathrm{pH} 5.2)$ to a final concentration of $0.3 \mathrm{M}$ and 3 volumes of absolute alcohol. The mixture was incubated at $-80^{\circ} \mathrm{C}$ overnight and RNA was recovered by centrifuging at 14,000 $\mathrm{rpm}$ for $20 \mathrm{~min}$ at $4^{\circ} \mathrm{C}$.The RNA was rinsed with $70 \%$ ethanol and recovered by centrifuging at $10,000 \mathrm{rpm} 5 \mathrm{~min}$ at $4^{\circ} \mathrm{C}$.Ethanol was removed by air drying the sample and the pellet was dissolved in $10 \mu \mathrm{l}$ of DEPC-treated water and the RNA was treated with RQ-1 DNAse (Promega).

\section{Analyses of Quality and Quantity of the Extracted RNA}

\section{Purity and integrity of the extracted RNA}

The concentration and purity of the extracted RNA samples were quantified spectrophotometrically (Biospecnano spectrophotometer, Shimadzu, Japan) at $A_{230}, A_{260}$ and $\mathrm{A}_{280} \mathrm{~nm}$ by diluting the RNA sample in DEPC-treated water to detect polysaccharide/polyphenolic contaminations and protein contaminations. The absorption ratios $\mathrm{A}_{260} / 230$ and $\mathrm{A}_{260} / 280$ were used to detect polysaccharide/polyphenolic contaminants and protein contaminants, respectively (Iandolino et al., 2004; Zhen et al., 2011). The ratio of $\mathrm{A}_{230: 260: 280}$ of the RNA samples was also quantified as a measure of purity (Iandolino et al., 2004). Integrity of the RNA samples was assessed on a $2 \%$ denaturing formaldehyde agarose gels by electrophoresis at 50V (Vasanthaiah et al., 2008).

\section{Construction of cDNA library}

The extracted total cellular RNA from peel tissues of banana collected at different times of inoculation with $C$. musaewas purified by magnetic bead- mRNA purification kit (Dynal Biotech ASA, Invitrogen, USA) and cDNA synthesis was done by Superscript first strand synthesis system for RT-PCR (Invitrogen, USA). The cDNA library construction was done using pDONR ${ }^{\mathrm{TM}} 222$ cloning vector by Cloneminer 11 cDNA library construction kit 
(Invitrogen, USA). The constructed cDNA library mix was dispensed into several Eppendorf tubes and stored at $-80^{\circ} \mathrm{C}$ until further use. Titer of the cDNA library mix was checked by spreading a $25 \mu \mathrm{l}$ of cDNA library mix on LB medium supplemented with Kanamycin $\left(50 \mu \mathrm{gml}^{-1}\right)$. Size of the cDNA inserts in clones of the cDNA library was estimated by selecting ten random cDNA clones. The cDNA inserts of the selected clones were amplified using M13 specific primers as M13 sequences are flanking the cDNA insert region of the cDNA clones constructed using $\mathrm{pDONR}^{\mathrm{TM}} 222$ vector. A few of the amplified cDNA inserts (i.e. PCR products) were subjected to DNA sequencing and subsequent homology search with NCBI BLAST and ESTtik BLAST databases (www.musagenomics.org/esttik.cirad.fr). Accession numbers of the sequenced PCR products of five selected cDNA clones were obtained from the EMBL (i.e. European Molecular Biology Laboratories, UK).

\section{RT-PCR analysis}

Total cellular RNA from extraction method No 3 was purified by the magnetic bead-mRNA purification kit and mRNA was obtained. The cDNA was synthesized from $2 \mu \mathrm{l}$ of total RNA extracted by the extraction method No3 using peel samples of cultivars Seenikesel, Kolikuttu, Emban, Embul, and Alukeselby Superscript RT First Strand Synthesis kit (Invitrogen, USA). Quality of the extracted mRNA was assured by the construction of cDNA from purified mRNA. Concentration and purity of cDNA were measured using a Biospecnano spectrophotometer (Shimadzu, Kyoto, Japan). Furthermore, the success of cDNA synthesis was confirmed by amplifying the housekeeping genes (i.e. Internal control genes for RT-PCR) RPS-2 gene using the primer pair 5'- TAG GGA TTC CGA CGA TTT GT-3' and 5'- TAG CGT CAT CAT TGG CTG GGAG-3' and MaEBF-1 gene using the primer pair 5'- CCT CAA TAA GCG ATT ACG GTG-3' and 5'TCA GAC TCC CAA GAG ATT CC-3'(Chen et al.,2011) with the synthesized cDNA. Thereafter, one of the putative genes deduced based on the sequence information of a cDNA insert of a selected clone was amplified by RT-PCR. The putative gene of the ETS sequence (Accession No. HF567810)given by the selected cDNA clone was homologous to Gama glutamyltransferasegene (GGT) and the following primer pair was designed for the amplification of putative Gama glutamyltransferasegene (i.e. 5'-TAT GGA AGA CCC TTG GAT-3' and 5'-CAC TTT CTT CCA TGG CAC CT-3'). The PCR reaction conditions were maintained for 40 cycles at $95{ }^{\circ} \mathrm{C}$ for $2 \mathrm{~min}$, denaturation at $95{ }^{\circ} \mathrm{C}$ for $30 \mathrm{sec}$, annealing at $60^{\circ} \mathrm{C}$ for $30 \mathrm{sec}$, extension at $72{ }^{\circ} \mathrm{C}$ for $2 \mathrm{~min}$ and final extension at $72{ }^{\circ} \mathrm{C}$ for $5 \mathrm{~min}$ for amplification of the RPS-2 and MaEBF-1genes. Amplification of the GGT transcript was done under the same PCR conditions with the exception of the annealing temperature of 58 ${ }^{\circ} \mathrm{C}$ for $30 \mathrm{sec}$.

\section{RESULTS AND DISCUSSION}

\section{Purity and integrity of RNA}

Purity and concentration of the RNA, extracted by the three methods and determined spectrophotometrically, are given in Table 1 . 
Table 1. Yield and quality of total RNA extracted by the three methods from peel tissues of banana fruits of cultivars Seenikesel, Kolikuttu and Alukesel.

\begin{tabular}{|c|c|c|c|c|c|}
\hline Protocols & Cultivar & A 260/230* & A $260 / 280 *$ & $\begin{array}{c}\mathbf{A}_{230}: \mathbf{A}_{260}: \mathbf{A}_{280} \\
*\end{array}$ & $\begin{array}{l}\quad \text { Yield } \\
(\mu \mathbf{g} / \mathbf{g} \\
\mathbf{F W})^{*}\end{array}$ \\
\hline Extraction & Seenikesel & 0.65 & 1.09 & $1: 1.4: 1.8$ & 28.94 \\
\hline method & Kolikuttu & 0.58 & 1.15 & $1: 1.4: 1.8$ & 29.42 \\
\hline No. 1 & Alukesel & 0.25 & 0.65 & 1:1.4:1.8 & 19.81 \\
\hline Extraction & Seenikesel & 1.35 & 1.38 & $1: 0.6: 1.7$ & 56.40 \\
\hline method & Kolikuttu & 1.30 & 1.32 & $1: 0.6: 1.7$ & 58.23 \\
\hline No. 2 & Alukesel & 0.82 & 1.04 & 1:0.6:1.7 & 48.68 \\
\hline Extraction & Seenikesel & 2.03 & 2.01 & $1: 2: 1$ & 238.10 \\
\hline method & Kolikuttu & 1.92 & 2.08 & $1: 2: 1$ & 242.62 \\
\hline No. 3 & Alukesel & 1.68 & 1.65 & $1: 2: 1$ & 108.36 \\
\hline
\end{tabular}

*Results are expressed as the mean values of extractions from three different cultivars.

Absorption ratios of $\mathrm{A}_{260} / \mathrm{A}_{230}, \mathrm{~A}_{260} / \mathrm{A}_{280}$ and $\mathrm{A}_{230}: \mathrm{A}_{260}: \mathrm{A}_{280}$ are measures to determine RNA quality. $A_{260} / A_{230}$ and $A_{260} / A_{280}$ ratios near 2.0 were given by the method No. 3, indicating the absence of significant contaminations with polysaccharides and phenolic materials respectively, in the RNA extracted. Normally a 1:2:1 ratio in the $A_{230: 260: 280}$ is expected in high purity RNA isolates and such a ratio was observed in the extraction method No. 3.

The RNA extracted by methodsNos.1, 2 and 3 from cultivars Seenikesel, Kolikuttu and Alukeselare shown in Figures 1a, 1b and 1c, respectively, when separated on a 2\% denaturing agarose gel. The RNA extracted by the methods 1 and 2 (Figures 1a and 1b) and analyzed on $2 \%$ denaturing agarose gel, did not show clear and intense bands representing $18 \mathrm{~s}$ and $28 \mathrm{~s}$ rRNA along with a smear showing additional rRNA (between 18s and 5s rRNA) that should be present in a high quality RNA sample (Vasanthaiah et al., 2008). In comparison to methods No. 1 and 2, the protocol implemented in method No. 3 gave a better separation of $28 \mathrm{~s}$ rRNA and 18s rRNA bands on $2 \%$ denaturing agarose gel. In addition to the intense, resolved ribosomal bands, a smear of RNA could be observed and genomic DNA closer to the wells of the gel is not visible (Figure 1c).

During the extraction of RNA by extraction methods No. 1 and 2, the final RNA precipitate developed a brown colour. This indicated that purification steps of methods No. 1 and 2 are not sufficient to remove all polysaccharides and polyphenols in the samples.

The method No. 3 was able to extract the total cellular RNA from a range of banana cultivars

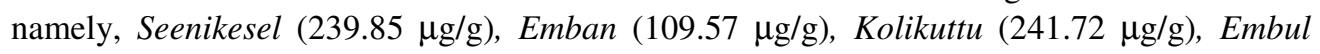
$(106.20 \mu \mathrm{g} / \mathrm{g})$ and Alukesel $(107.93 \mu \mathrm{g} / \mathrm{g})$. Denaturing agarose gel electrophoresis indicated that the extracted RNA was of good quality and integrity to be used in downstream applications such as cDNA construction, sequencing and gene expression analysis by RTPCR (Fig. 2). 


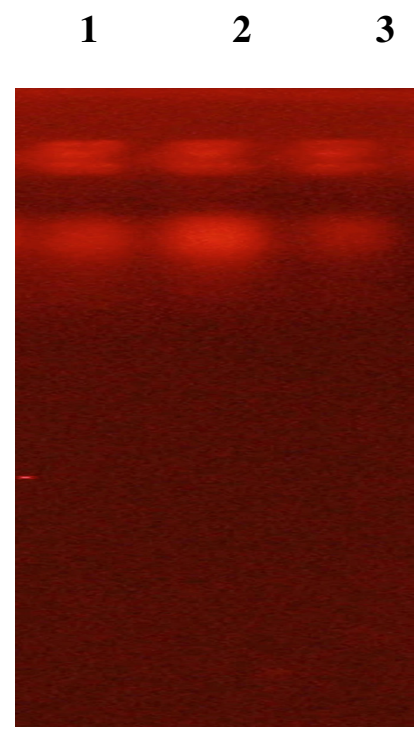

(a)

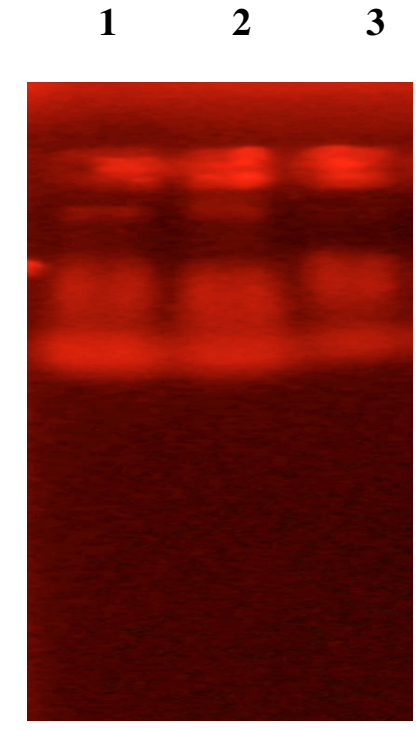

(b)

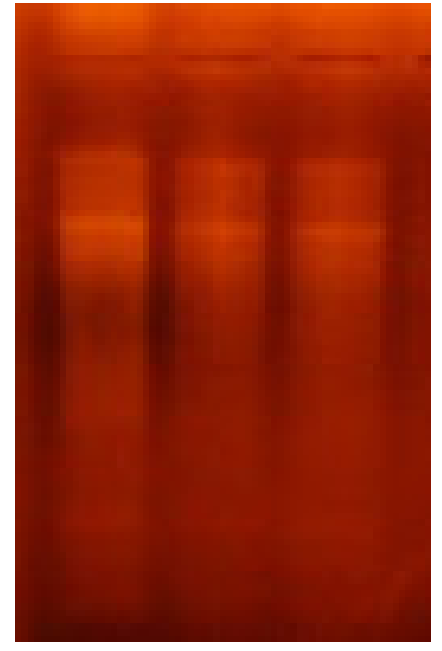

(c)

Fig. 1. Total cellular RNA (8 $\mu$ l RNA) extracted from the extraction methods No. 1 (a), 2 (b) and 3 (c), and analyzed by $2 \%$ denaturing agarose gel electrophoresis. Lanes 1-3 indicate the RNA extracted from banana cultivarsSeenikesel, Kolikuttu and Alukesel, respectively.

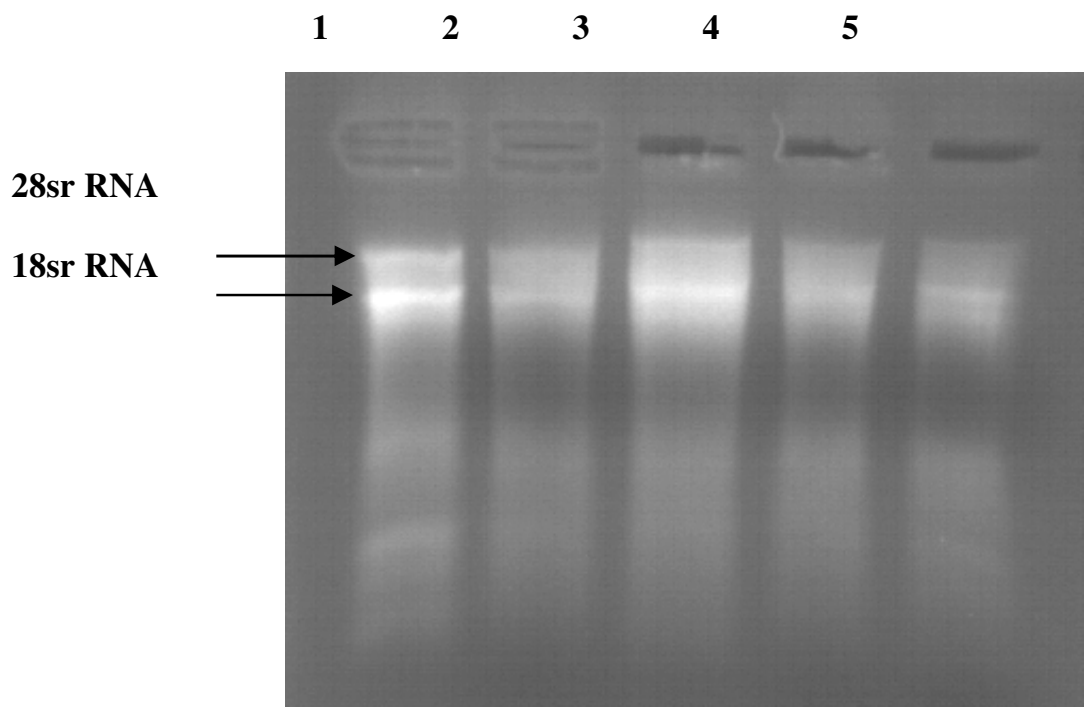

Fig. 2. Total cellular RNA extracted from the developed protocol (i.e. extraction method No. 3) analyzed by $2 \%$ denaturing agarose gel electrophoresis $(8 \mu \mathrm{l}$ of total cellular RNA). Lanes 1-5 contain RNA extracted from banana cultivarsSeenikesel, Emban, Kolikuttu, Embuland Alukesel, respectively. 
After verifying the quality of RNA samples, the mRNA were extracted from paramagnetic particle technique using Dynal beads. The concentration of poly (A) + RNA was $0.24 \mu \mathrm{g} / \mu \mathrm{l}$. Then, $2.4 \mu \mathrm{g}$ of poly $(\mathrm{A})+$ RNAs was reverse transcribed in corresponding single stranded cDNAs and the doubled stranded cDNA (ds cDNA) that was synthesized and analyzed in $2 \%$ agarose gel showed that the size of cDNA fragments ranged from $100 \mathrm{~kb}$ to $1500 \mathrm{~kb}$ (Fig. 3).

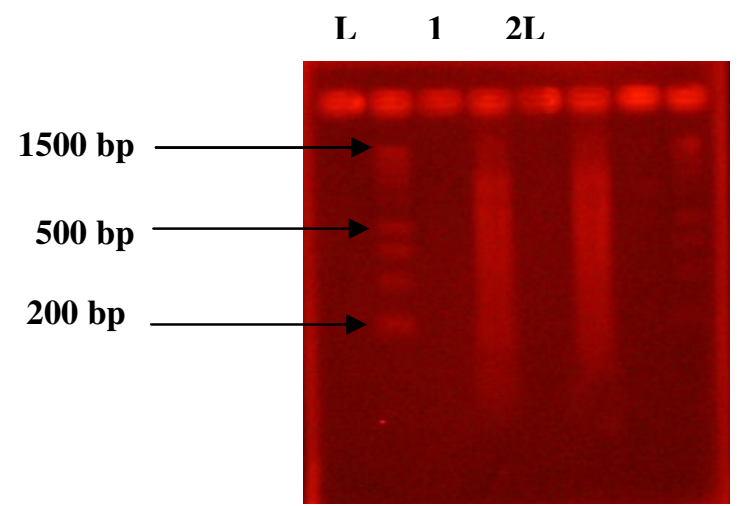

Fig. 3. Range of cDNA fragment size when analyzed on a $2 \%$ agarose gel.L- 100 bpmarker (Promega), Lanes 1 and 2 - cDNA constructed from RNA samples extracted fromcultivarSeenikesel by extraction method No. 3.

\section{Quality of cDNA library}

The cDNA library was constructed from the generated cDNA from extracted mRNA by using method No. 3 and it had a titer of $6.8 \times 10^{6} \mathrm{cfu} / \mathrm{ml}$. Fig. 4 shows the sizes of cDNA inserts of 10 selected cDNA clones. Inserts of the transcripts in cDNA clones ranged from 400 to $1200 \mathrm{bp}$. Moreover, the sequencing and homology search of PCR products of several transcripts of the selected cDNA clones revealed that they were homologous with transcripts of the Musa genome (Table 2). This indicates the successful construction of a cDNA library from the extracted mRNA.

$$
\begin{array}{lllllllllll}
\mathrm{L} & 1 & 2 & 3 & 4 & 5 & 6 & 7 & 8 & 9 & 10
\end{array}
$$

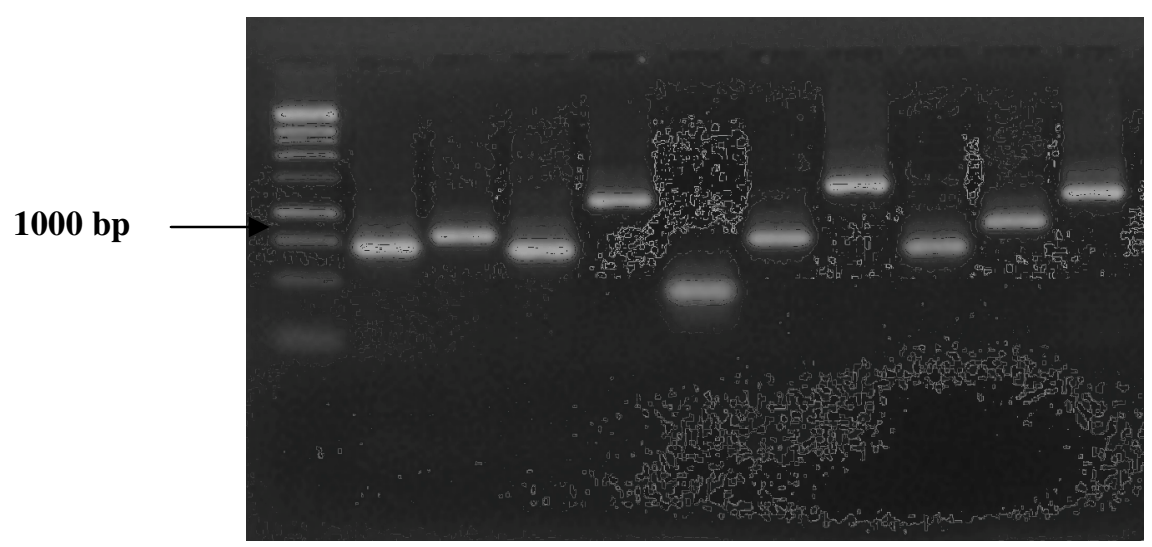

Fig. 4. PCR products amplified with M13 specific primers to determine the size of cDNA insert of ten selected cDNA clones (1-10). L- 1 kb ladder (Promega). 
Table 2. Sequencing and homology search of PCR products of several transcripts of the selected cDNA clones that were homologous with transcripts of the Musa genome

\begin{tabular}{|c|c|c|c|}
\hline Clone number & $\begin{array}{l}\text { Accession } \\
\text { Number }\end{array}$ & $\begin{array}{l}\text { Putative protein/ } \\
\text { Homologous host genome }\end{array}$ & $\begin{array}{c}\% \\
\text { Similarity }\end{array}$ \\
\hline MaSINI 184 & HF567809 & $\begin{array}{l}\text { Beta-1,3 Glucanase / } \\
\text { Musa acuminata }\end{array}$ & 98 (2.00E-63) \\
\hline MaSINI 507 & HF567824 & $\begin{array}{l}\text { Mitochondrial ATP synthase } \\
\text { G subunit family protein / } \\
\text { Musa balbisiana }\end{array}$ & $92(5.00 \mathrm{E}-61)$ \\
\hline MaSINI 565 & HF567826 & $\begin{array}{l}\text { Expansin1 / } \\
\text { Musa acuminata }\end{array}$ & 71 (2.00E-67) \\
\hline MaSINI 680 & HF567833 & $\begin{array}{l}\text { Germin-like protein/ } \\
\text { Musa acuminata }\end{array}$ & $94(7 e-101)$ \\
\hline MaSINI 693 & $\begin{array}{l}\text { Accession\#: } \\
\text { HF567835 }\end{array}$ & $\begin{array}{l}\text { Endochitinase /Musa } \\
\text { acuminata }\end{array}$ & $96(7.00 \mathrm{E}-132)$ \\
\hline
\end{tabular}

The cDNA constructed from total cellular RNA extracted from the extraction method No. 3 and its mRNA had $\mathrm{aA}_{260} / \mathrm{A}_{230}$ ratio greater than one, and the ratio of $\mathrm{A}_{260} / \mathrm{A}_{280}$ ranged from 1.65 to 1.8. As reported by Asif et al. (2000), the ratio of $\mathrm{A}_{260} / \mathrm{A}_{230}$ indicatedthat the RNA extractions are free from polysaccharides and polyphenols. The OD ratio of $\mathrm{A}_{260} / \mathrm{A}_{280}$ is also at a satisfactory level. The integrity of the synthesized cDNA assessed by $2 \%$ agarose gel is illustrated in Fig. 3.

Fig. 5 shows the PCR amplification of internal control genes MaEBF-1, Ribosomal Protein S-2 (RPS-2) and gene of interest GGTgenes using the synthesized cDNA from cultivars Seenikesel, Kolikuttu, Emban, Embul,Suwadeland Alukeselas the template DNA under inoculated and non-inoculated conditions of $C$. musae. The expected sizes of the PCR products of MaEBF-1 (280bp), RPS-2 (84bp) and GGT (171 bp) could be obtained indicating that successful amplification of the genes was possible.

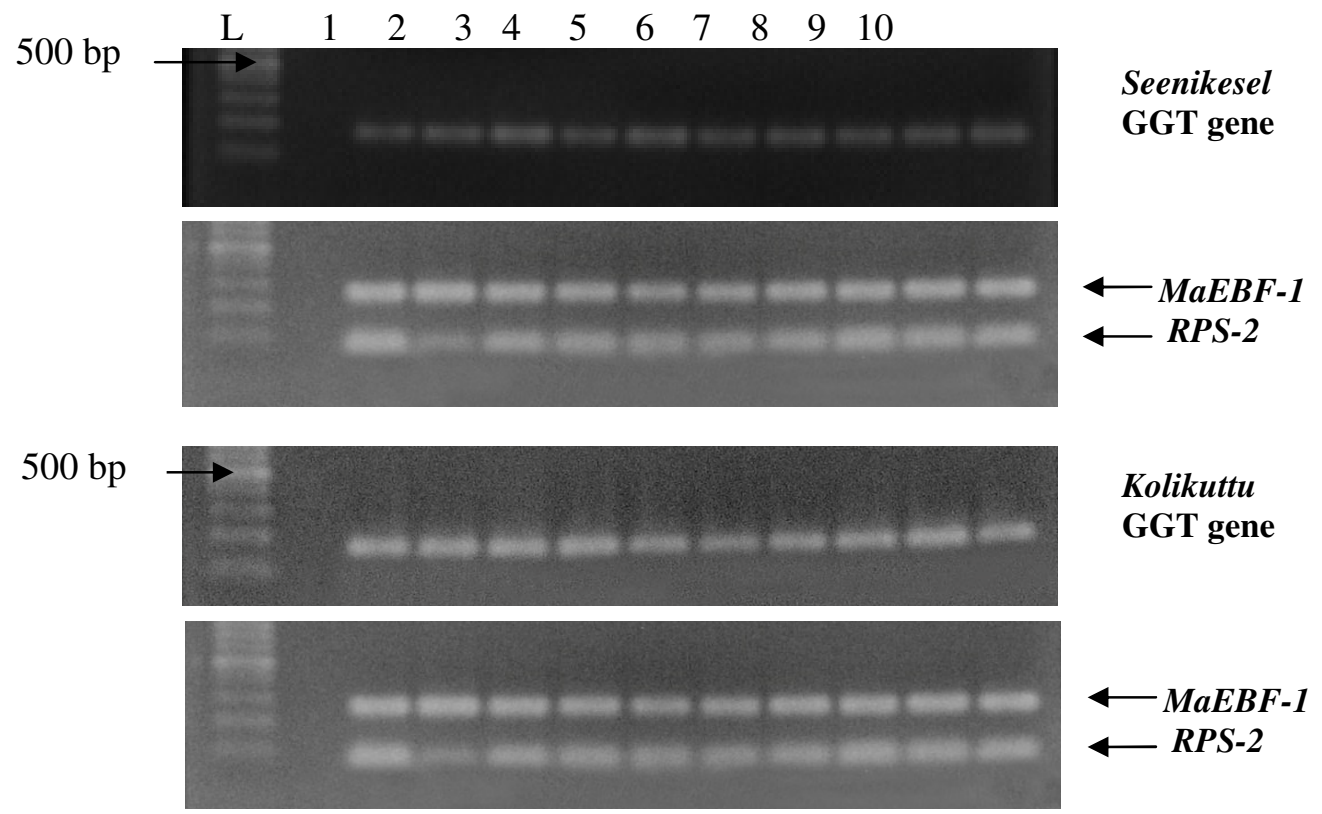




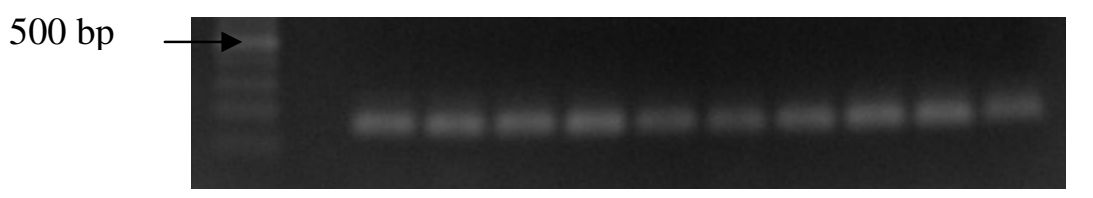

\section{Emban}

GGT gene

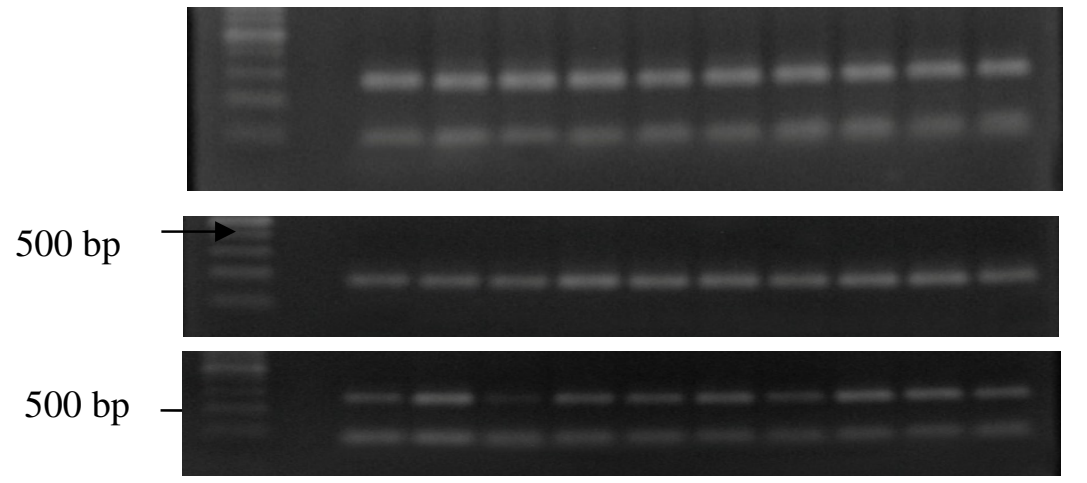

$\longleftarrow$ MaEBF-1

$\longleftarrow$ RPS -2

\section{Embul}

GGT gene
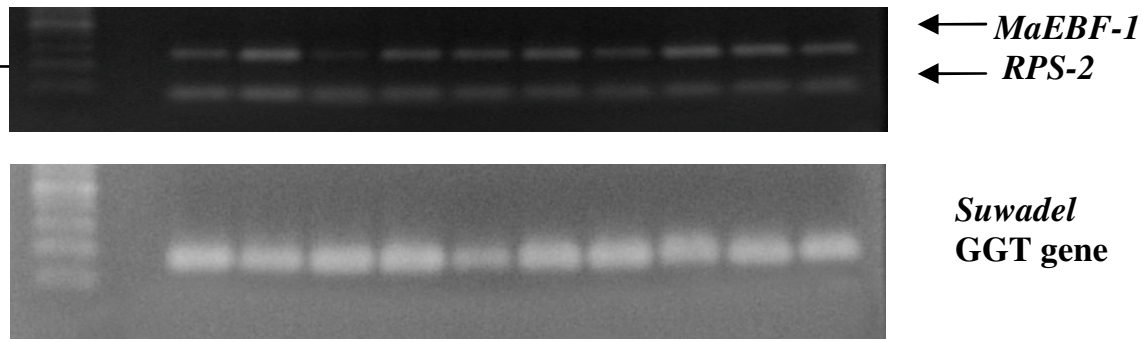

Suwadel

GGT gene

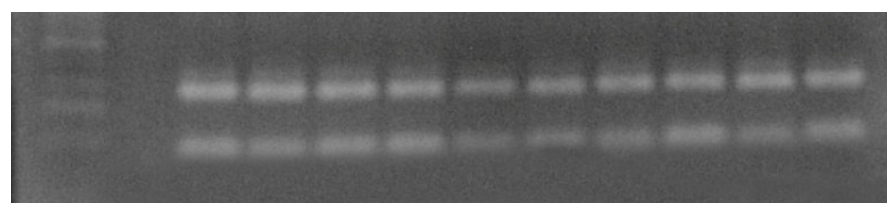
$\longleftarrow M a E B F-1$
$\longleftarrow$ RPS - 2

$500 \mathrm{bp}$

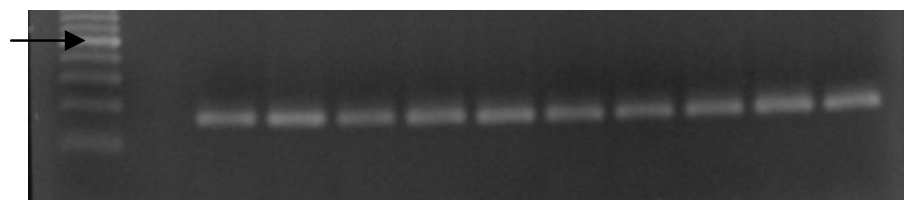

Alukesel

GGT gene

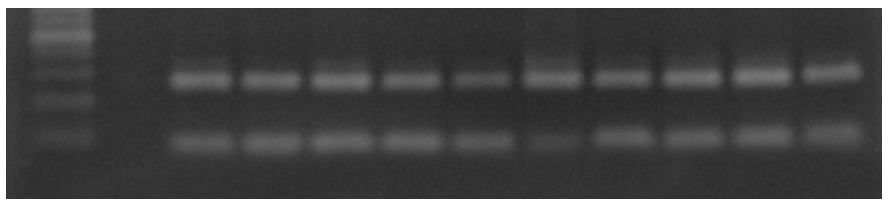
$\longleftarrow$ MaEBF-1
$\longleftarrow$ RPS-2

Fig. 5. RT-PCR products of the internal control genes $M a E B F-1$, Ribosomal Protein S 2 (RPS-2) and gene of interest Gama glutamyltransferace (GGT) transcript from cDNA constructed from the total RNA isolated from cultivarsSeenikesel, Kolikuttu, Emban, Embul, Suwadeland Alukeselby extraction method No. 3 with control and treatment cDNA samples for five time points. Lane L: 100bp DNA ladder (Promega), lane1-5 control samples: 1HAI, 24HAI, 48HAI, 96HAI, 144HAI respectively, lane 6-10 treatment samples: 1HAI, 24HAI, 48HAI, 96HAI, 144HAI respectively. cDNA was generated from $1 \mu \mathrm{g}$ of template RNA. Total volume of PCR product was separated on $2 \%$ agarose gel and electrophoresis was performed for 45 min at $50 \mathrm{~V}$. 
Different plant species and different parts of the same plant have specific physical and chemical characteristics of their own and contain various endogenous substances (Hughand Robert, 2006). Therefore, extraction methods to obtain good quality RNA should be designed to suit the specific physico-chemical properties of the tissue from which RNA is extracted. In the present study, three different extraction methods were tested for their effectiveness in extracting good quality RNA from banana peel tissue in which RNA extraction by standard established methods is difficult due to the presence of high concentrations of polyphenols, polysaccharides and latex. Our results have confirmed the success of extraction methodNo.3, which was developed through this study. This protocol is a modification of several RNA isolation protocols from plants as reported by Fütterer et al. (1995), Liu et al. (1998) and Asif et al. (2000).

The extraction methodNo.3 gave an adequate RNA yield ranging from 100 to $250 \mu \mathrm{gg}^{-1} \mathrm{FW}$, which is on par with RNA yields of successful extraction methods reported previously (Iandolino et al., 2004;Vasanthaiah et al., 2008). The spectrophotometric analyses and electrophoresis by denaturing gel electrophoresis confirmed the quality of the extracted RNA by method No.3 based on absorbance ratios and separation of ribosomal RNA bands (Vasanthaiah et al., 2008). Furthermore, RNA extracted from method No.3 had $\mathrm{A}_{260} / \mathrm{A}_{230}$ and $\mathrm{A}_{260} / \mathrm{A}_{280}$ ratios of 1.87 and 1.92 , respectively, which are within the expected range of samples having no contaminations of polysaccharides, polyphenolics and proteins. These levels of quality and integrity of extracted RNA are comparable to those obtained by standard methods by many other workers (Zhen et al., 2011; Gesteira et al., 2003; Vasanthaiah et al., 2008; Meisel et al., 2005).

The method No. 2 employed in this study is a combination of the methods used by Liu et al. (1998) and Asif et al. (2000) to extract RNA from banana plant tissues. However, in the present study, this method failed to yield good quality RNA from banana peel tissues especially when the peel tissue sample had a combination of mature and ripen stages. The banana peel tissue undergoes significant changes in structural and soluble metabolites such as polyphenols, polysaccharides and specific proteins during the fruit maturing phase (Iandolino et al., 2004). Hence, peel tissues collected from different maturity stages and from different varieties could have significant variations in the above chemical compounds which inhibit or lower the efficiency of RNA extraction.

Several specific features of extraction method No. 3 may have contributed to its ability to extract high quality RNA suitable for functional genomics studies such as cDNA library construction and RT-PCR. Firstly, it used pre-warmed extraction buffer, which removes only the contaminating phenols and proteins without affecting the RNA yield (Vasanthaiah et al., 2008). Moreover, pre-warmed extraction buffer helps to inactivate RNase activity which is high in mature plant tissues (Vasanthaiah et al., 2008). The extraction buffer used in method No. 3 contained boric acid, which together with $\beta$-mercaptoethanol, facilitates the recovery of RNA by enhancing the dissolution of cell walls in peel tissues of different maturity stages and by the denaturation of proteins. Further, itinhibits oxidation of the endogenous phenolic compounds and subsequent binding of phenolics to RNA (Wan and Wilkins, 1994). Moreover, polyphenol oxidase activity can be reduced by the highly alkaline $\mathrm{pH}$ of the extraction buffer (Gesteira et al., 2003). The extraction buffer used in the method No. 3 contained $\mathrm{CTAB}$, which is a surfactant used as a cell disrupting agent in RNA extraction protocols of recalcitrant plant species and plants with high polyphenolic compounds and polysaccharides (Rubio-Piñ and Zapata-Pérez, 2011).Therefore, CTAB included in the extraction buffer of methodNo.3has an advantage over the extraction buffers used in the other two methods. These could have contributed to the higher quantity of extracted RNA 
per unit fresh weight of peel tissue and to the absence of a brown colour appearance in the final RNA precipitate of extraction methodNo.3. The brown colour indicated the presence of proteins, carbohydrates and phenolic compounds mixed with the extracted RNA (Rubio-Pin and Zapata-Pérez, 2011).

Furthermore, the method No. 3 has an extraction period of up to three days with overnight precipitation, to recover adequate quantity of RNA. According to Vasanthaiah et al. (2008), for mature and disease-infected tissues that contain higher amounts of polyphenols, polysaccharides and other interfering compounds, it is necessary to extend the extraction period up to three days. In the extraction method No. 3, more extraction steps with phenol/chloroform/isoamyl alcohol were involved. Also, the addition of sodium acetate used at two steps of the extraction procedure may have contibuted positively for elimination of polysaccharides which is the role of sodium acetate in RNA protocols (Rubio-Piñ and Zapata-Pérez, 2011). Moreover, the method No. 3 used higher centrifugation speeds (i.e. $12000-14000 \mathrm{rpm}$ ) in comparison to the other two methods (i.e. $10000 \mathrm{rpm}$ ). Above modifications of the RNA extraction in method No. 3 could have improved its quality and quantity of RNA extracted in comparison to the RNA obtained from the other two methods.

\section{CONCLUSION}

Extraction of good quality RNA from banana fruit peel tissues is a difficult task due to their higher polyphenol and polysaccharide concentrations. The modified protocol (i.e. extraction method No. 3) with the inclusion of a high concentration of pre-warmed Tris-Borate extraction buffer containing $\mathrm{CTAB}$ and a three-day extraction step yielded adequate quantities of good quality RNA. Intact RNA, $\mathrm{A}_{260} /{ }_{230} \mathrm{~nm}$ ratios greater than one and $\mathrm{A}_{260} / 280$ ratios of almost two, cDNA profile, sequence data of cDNA inserts, successful RT-PCR of a housekeeping genes and a putative Gama glutamyltransferese (GGT) gene confirmed the quality of RNA. This method is especially useful for extracting RNA from a combination of mature green, ripe and disease-infected peel tissues of a range of banana cultivars including both desert and cooking-types.

\section{ACKNOWLEDGEMENT}

Financial assistance by National Research Council (Grant no. 07-42) is gratefully acknowledged.

\section{REFERENCES}

Anthony,S., Abewickrama, K., Dayananda, R., Santhi,W.W. and Arabewela, L. (2004). Fungal pathogens associated with banana fruit in Sri Lanka, and their treatments with essential oil. Mycopathologia, 157(1), 91 - 97.

Asif, M.H., Dhawan,P. and Nath,P.A. (2000). Simple procedure for the isolation of high quality RNA from ripening banana fruit. Plant Molecular Biology Reporter, 18(2), 109 - 115.

Chen, L., Zhong, H., Kuang, J., Li, J., Lu, W. and Chen, J. (2011). Validation of reference genes for RT-qPCR studies of gene expression in banana fruit under different experimental conditions. Planta., 234, 377 - 390. 
Clendennen, S.K. and May, G.D. (1997). Differential gene expression in ripening banana fruit. Plant physiology, 115(2), 463 - 469.

Coomaraswamy, U., Hirimburegama, K., Vidanapathirana, N., Rohanadeera, H., Nandika, N., Indunil, Y., Thilini, M., Thennakoon, M. and Kanthi, A. (2009). Magampura Institute of Agro Technology and Rural Sciences, University of Colombo. [on line]. [Accessed on 03.01.2011]. Available at http://wikieducator.org/Sri_Lanka/L3_Farmers/University_of_Colombo.

De Costa, D.M. and Chandima, A.A.G. (2014). Effect of exogenous pH on development and growth of Colletotrichummusae and development of anthracnose in different banana cultivars in Sri Lanka. Journal of the National Science Foundation of Sri Lanka, 42(3), 203 214.

Lapeyre de Bellaire, L., Chillet, M., Dubois, C. and Mourichon, X. (2000). Importance of different sources of inoculum and dispersal methods of conidia of Colletotrichummusae, the causal agent of banana anthracnose, for fruit contamination. Plant Pathology, 49(6),782 790.

Doyle, J.J. and Doyle, J.L. (1987). A rapid DNA isolation procedure for small quantities of fresh leaf tissue.Phytochem Bull., 19, 11 - 15.

Fütterer, J., Gisel, A., Iglesias,V., Kloti, A., Kost, B., Mittelsten, Scheid, O., Neuhaus, G., Neuhaus-Url, G., Schrott, M., Shillito, R. et al. (1995). Standardmolecular techniques for the analysis of transgenic plants. In: Gene Transfer to Plants. (Eds. I. Potrykusand G. Spangenberg), pp. 218-204. Springer-Verlag, Berlin.

Ekanayake, E.M.D.S., Samarasinghe, W.L.G. and Ariyarathna, I. (2002). Collection, Characterization, Evaluation, Identification \& Conservation of Musa genetic resources in Sri Lanka, Plant Genetic Resource Center in Gannoruwa.

Gesteira, A.S., Micheli, F., Ferreira, C.F. and Cascardo, J.C. (2003). Isolation and purification of functional total RNA from different organs of cacao tree during its interaction with the pathogen Crinipellisperniciosa.BioTechniques, 35(3), 494 - 500.

Hugh, D. and Robert, W. M. (2006). Protocol for the analysis of n-alkanes and other plantwax compounds and for their use as markers for quantifying the nutrient supply of large mammalian herbivores.Nature Protocols, 1, 680 - 1697.

Iandolino, A.B., Goes Da Silva, F., Lim, H., Choi, H., Williams, L.E. and Cook, D.R. (2004). High-quality RNA, cDNA, and derived EST libraries from grapevine (Vitisvinifera L.).Plant Molecular Biology Reporter, 22(3), 269 - 278.

Kader, A.A. (2005). Banana: Recommendations for maintaining postharvest quality. [on line]. [Accessed on 01.05.2010]. Available at

http://postharvest.ucdavis.edu/Produce/ProduceFacts/Fruit/full_banana_ripening chart.shtml.

Lassois, L., Jijakli,M. H., Chillet, M. and de Lapeyre de Bellaire, L. (2010). Crown rot of bananas: Preharvest factors involved in postharvest disease development and integrated control methods. Plant disease, 94(6), 648 - 658. 
Liu, J.J., Goh, C.J., Loh, C.S., Liu, P. And Pua, E.C. (1998). A method for isolation of total RNA from fruit tissues of banana. Plant Molecular Biology Reporter, 16 (1), 1-6.

Logemann, J., Schell, J.and Willmitzer, L. (1987). Improved method for extraction of RNA from plant tissues. Analytical Biochemistry, 163(1), 16 - 20.

Meisel, L., Fonseca, B., Gonzalez, S., Baezayates, R., Cambiazo, V., Campos, R., Gonzalez, M., Orellana, R., Retamales, J. and Silva, H. (2005). A rapid and efficient method for purifying high quality total RNA from peaches (Prunuspersica) for functional genomics analyses. Biological Research, 38, 83 - 88.

Rubio-Piña, J.A. and Zapata-Pérez, O. (2011). Isolation of total RNA from tissues rich in polyphenols and polysaccharides of mangrove plants. Electronic Journal of Biotechnology, 14(5): http://dx.doi.org/10.2225/vol14-issue5-fulltext-10.

Vasanthaiah, H.K.N., Katam, R. and Sheikh, M.B. (2008). Efficient protocol for isolation of functional RNA from different grape tissue rich in polyphenols and polysaccharides for gene expression studies. Electronic Journal of Biotechnology, 11(3), 1 - 8.

Wan, C.Y. and Wilkins, T.A. (1994). A modified hot borate method significantly enhances the yield of high-quality RNA from cotton (Gossypiumhirsutum L.). Analytical Biochemistry, 223, 7 - 12.

Zhen, L-N., Wang, K., Zhang, Y-J. and Zhou, H. (2011). A method for high-quality RNA extraction from tall fescue. African Journal of Biotechnology, 10(37), 7161 - 7165. 